\title{
COLORIMETRIC DETECTION OF SILVER IONS IN AQUEOUS SOLUTIONS USING THIOL FUNCTIONALIZED MAGNETIC CORE-SHELL $\mathrm{Fe}_{3} \mathrm{O}_{4} @ \mathrm{SiO}_{2}$
}

\author{
S. Kavitha ${ }^{1,}$, A. Anand Babu Christus ${ }^{2}$ and S. Mary Jelastin Kala ${ }^{3}$ \\ ${ }^{1}$ Department of Chemistry, The M.D.T Hindu college (Affiliated to Manonmaniam Sundaranar \\ University, Tirunelveli.), Tirunelveli-627010, Tamil Nadu. \\ ${ }^{2}$ Department of chemistry, SRM Institute of Science and Technology, Ramapuram campus, \\ Ramapuram-600089, Chennai, Tamil Nadu \\ ${ }^{3}$ Research Department of Chemistry, St. Xavier's College (Affiliated to Manonmaniam \\ Sundaranar University, Tirunelveli.), Tirunelveli-627002, Tamil Nadu \\ Corresponding Author: kavithasundar2010@gmail.com
}

\begin{abstract}
Thiol functionalized magnetic silica-core shell (MPTES- $\mathrm{Fe}_{3} \mathrm{O}_{4} @ \mathrm{SiO}_{2}$ ) is used in the colorimetric sensor for the recognition of silver ions. This detected system acts more sensitive and selectively for silver ions in real-time applications. Thiol functionalized core-shell magnetic nanoparticles interact with silver ions to form a metal-thiol complex with the appearance of yellow color in the solution with surface resonance peak $\left(403 \mathrm{~cm}^{-1}\right)$ in $\mathrm{UV}_{\mathrm{V}} \mathrm{spectra}$. This colorimetric sensor is very cheap, and facile in the detection of a silver ion with the lower limit of the detection value of $10 \mathrm{~nm}$. Furthermore, we have applied for the monitoring of the real samples of this sensing system with good recovery results.
\end{abstract}

Keywords: Thiol, Silica, $\mathrm{Fe}_{3} \mathrm{O}_{4}$, Colorimetric, Silver, Real Water Samples

RASĀYAN J. Chem., Vol. 14, No.3, 2021

\section{INTRODUCTION}

Heavy metals naturally occur in the earth's crust. Anthropogenic activity like mining and other industrial applications may lead to an increase in the concentration of toxic metal ions in the plant, animal and human tissues. The potential toxicity of this heavy metal is specially noted from a health and environmental point of view. The World Health Organization listed out the major toxic heavy metals for major public concern, such as cadmium, mercury, silver, copper, lead, arsenic, selenium, manganese, chromium, cobalt, nickel and zinc, ${ }^{1-8}$. Among the different heavy metals, silver is extensively used in major industries such as jewelry, electroplating, photography, anticorrosive alloys and mirrors. The rapid utilization of silver in industries leads to contamination of soluble silver in aquatic bodies. It has been reported that nearly 80 tons of silver were contaminated with surface water every year. The public consumption of water containing silver more than $0.9 \mathrm{mmol} / \mathrm{L}$ is toxic. Higher consumption leads to the deposition of silver in the body tissues resulting in a disease called argyria. The symptoms of this the disease are changing in coloration noticed in the eyes, skin and mucous membranes. The gray coloration of this tissue, sometimes wrongly diagnosed as symptoms of cyanosis..$^{9-10}$

Several conventional methods have been employed for the investigation of trace-level silver ions in aqueous solution, including atomic absorption/emission spectroscopy ${ }^{11}$, inductively coupled plasma mass spectroscopy (ICP-MS) ${ }^{12}$ and ion-selective electrodes. Although these techniques are very sensitive, there are some drawbacks to these techniques. It requires highly sophisticated tools, a more expensive and complicated preparation process which limits the use of this technique in the detection process. More recently, organic species, molecular complexes, nanomaterials, quantum dots and DNA-based materials have been adopted as fluorescent and electrochemical sensors to detect $\mathrm{Ag}^{+}$. As far as our knowledge, metal cation sensors based on coordination-driven discrete molecular containers are extremely infrequent.

Rasayan J. Chem., 14(3), 1803-1808(2021)

http://doi.org/10.31788/RJC.2021.1436437

This work is licensed under a CC BY 4.0 license. 
RASĀYAN J. Chem.

Vol. 14 | No. 3 |1803-1808| July - September | 2021

The most practical and convenient sensors are colorimetric as compared with other fluorescent and electrochemical sensors, colorimetric methods are more superior to others by their properties like an economical, simple instrument, facial procedure and visual appearance in bare eyes after incorporating a specific type of metal ions, even at very low analyte concentrations. ${ }^{13,14}$

Thiol functionalized magnetic silica-core shell nanoparticles (MPTES- $\mathrm{Fe}_{3} \mathrm{O}_{4} @ \mathrm{SiO}_{2}$ ) are used in the colorimetric sensor for the recognition of silver ions. ${ }^{15,16}$ This sensing system act as an extremely sensitive and choosy detection of silver ions in real-time applications. Thiol functionalized core-shell magnetic nanoparticles interact with the silver ions to form a metal-thiol complex with an appearance of yellow color in the solutions with the surface resonance peak observed at $403 \mathrm{~nm}$ in UV spectra. This colorimetric sensor is an inexpensive and simple way of detection process with a good limit of detection value as $10 \mathrm{~nm}$. Furthermore, we have applied this sensing system for the monitoring of the real water samples with good recovery results.

\section{Materials}

$\mathrm{FeCl}_{3} .2 \mathrm{H}_{2} \mathrm{O}$, ethylene glycol, silver nitrate, 3-mercaptopropyltrimethoxysilane (3-MPTS), and tetraethylorthosilicates (TEOS) were procured from Sigma Aldrich in India. Ammonia solution and hydrochloric acid $(\mathrm{HCl}, 37 \%)$, were purchased from Merck (India).

\section{Preparation of $\mathrm{Fe}_{3} \mathrm{O}_{4}$ Nanoparticles}

The magnetic nanoparticles were synthesized by a solvothermal method. In a $100 \mathrm{ml}$ beaker, $50 \mathrm{ml}$ of ethylene glycol was taken, to this Sodium acetate $(3.60 \mathrm{~g})$ and $\mathrm{FeCl}_{3} .6 \mathrm{H}_{2} \mathrm{O}(1.35 \mathrm{~g})$ were dispersed and the mixer is continuous stirred with a magnetic stirrer till the solution color turns to yellow. Then the solution is heated for $8 \mathrm{~h}$. at $200^{\circ} \mathrm{C}$ in a stainless-steel autoclave coated with Teflon. The obtained product was cooled and washed sufficiently with ethanol followed by distilled water. Then allowed to dry in a hot air oven at $65^{\circ} \mathrm{C}$ for $12 \mathrm{~h}$ and stored for further use.

\section{Synthesis of Silica-coated $\mathrm{Fe}_{3} \mathrm{O}_{4}$ Nanoparticles}

By the simple sol-gel method, Silica was coated on $\mathrm{Fe}_{3} \mathrm{O}_{4}$ nanoparticles. In a $10 \mathrm{ml}$ of ethanol solution, 1 mg of $\mathrm{Fe}_{3} \mathrm{O}_{4}$ nanoparticles was dispersed and sonicated for 30 minutes. In this solution ammonium hydroxide was included to maintain the solution $\mathrm{pH}$ and $3 \mathrm{ml}$ of tetraethylorthosilicates (TEOS) was incorporated and stirred in the solution for 24h. Then it was centrifuged to remove the $\mathrm{Fe}_{3} \mathrm{O}_{4} @ \mathrm{SiO}_{2} \mathrm{NPs}_{\mathrm{s}}$ and washed with ethanol followed by distilled water sufficiently to remove trace level unreacted chemicals.

\section{Preparation of Functionalized $\mathrm{Fe}_{3} \mathrm{O}_{4} @ \mathrm{SiO}_{2} \mathrm{NPs}$}

The synthesized $\mathrm{Fe}_{3} \mathrm{O}_{4} @ \mathrm{SiO}_{2}$ nanoparticles were activated by $100 \mathrm{ml} \mathrm{HCl}(1 \mathrm{M})$ for 12 hrs. After activation, it was brought back to neutral $\mathrm{pH}$ by washing with distilled water. The activated $\mathrm{Fe}_{3} \mathrm{O}_{4} @ \mathrm{SiO}_{2}$ further washed with $50 \mathrm{ml}$ of ethanol and $20 \mathrm{ml}$ toluene followed by three times. Then it was dispersed with toluene and shifted into a $100 \mathrm{ml}$ round bottom flask. To this $10 \mathrm{ml}$ of 3-MPTS was added. The mixture was kept for reflex under $60^{\circ} \mathrm{C}$ for $24 \mathrm{~h}$. After this period, the obtained product $\mathrm{Fe}_{3} \mathrm{O}_{4} @ \mathrm{SiO}_{2}-\mathrm{SH}$ nanoparticles were extracted from the solution by an external magnet and dried hot air oven. The schematic preparation of the proposed nanoparticles and the interaction between the silver ions are depicted in Scheme-1.

\section{Characterization}

\section{RESULTS AND DISCUSSION}

The morphology of $\mathrm{Fe}_{3} \mathrm{O}_{4}$ and $\mathrm{Fe}_{3} \mathrm{O}_{4} @ \mathrm{SiO}_{2}$ is represented in Fig.-1(a) and (b). In Fig.-1a, the multi-dispersed nanoparticles, $\mathrm{Fe}_{3} \mathrm{O}_{4}$ nanoparticles with spherical shape are perceptible. After mixing $\mathrm{Fe}_{3} \mathrm{O}_{4}$ nanoparticles with silica it was prominent that the dark $\mathrm{Fe}_{3} \mathrm{O}_{4} \mathrm{NP}$ well implanted in the light gray $\mathrm{SiO}_{2} \mathrm{matrix}$ and constructed $\mathrm{Fe}_{3} \mathrm{O}_{4} @ \mathrm{SiO}_{2}$. Wide-angle XRD spectrum of $\mathrm{Fe}_{3} \mathrm{O}_{4}, \mathrm{Fe}_{3} \mathrm{O}_{4} @ \mathrm{SiO}_{2}$ is shown in Fig.-2(a). It shows seven peaks resolved at 18.1, 30.1, 35.4, 37.0, 53.3, 56.9 and 62.5 according to JCPDS \# $890691 .{ }^{14}$ This peak shows that these samples are in the inverse spinel structure of $\mathrm{Fe}_{3} \mathrm{O}_{4}$ and new peaks with broadband centered at $2 \theta=22^{\circ}$ have appeared assigned to the amorphous form of $\mathrm{SiO}_{2}$ Further confirmation of surface groups of core-shell magnetic nanoparticles are examined in FT-IR spectra (Fig.-2(b). Three 


\section{RASĀYAN J. Chem.}

Vol. 14 | No. 3 |1803-1808| July - September | 2021

types of materials $\mathrm{Fe}_{3} \mathrm{O}_{4}, \mathrm{Fe}_{3} \mathrm{O}_{4} @ \mathrm{SiO}_{2}$ and $\mathrm{Fe}_{3} \mathrm{O}_{4} @ \mathrm{SiO}_{2}-\mathrm{SH}$ show a wide band around $580 \mathrm{~cm}^{-1}$ was assigned to $\mathrm{Fe}-\mathrm{O}$ band stretching. Whereas the large band observed at $3400 \mathrm{~cm}^{-1}$ was ascribed to the band stretching of the $\mathrm{O}-\mathrm{H}$ bond. The appearance of a strong band around the $100 \mathrm{~cm}^{-1}$ was attributed to the SiO-Si stretching of $\mathrm{Fe}_{3} \mathrm{O}_{4} @ \mathrm{SiO}_{2}$-SH. In the FT-IR spectrum of $\mathrm{Fe}_{3} \mathrm{O}_{4} @ \mathrm{SiO}_{2}$-SH, there is no absorption peak for the - $\mathrm{SH}$ group since it possesses very low thiol content and less IR sensitivity. The stretching frequency at 2900 and $2850 \mathrm{~cm}^{-1}$ was attributed to the stretching of the $\mathrm{C}-\mathrm{H}$ methylenes of the alkyl chain. This confirms that the MPTS is effectively bounded on the surface of $\mathrm{Fe}_{3} \mathrm{O}_{4} @ \mathrm{SiO}_{2}$.

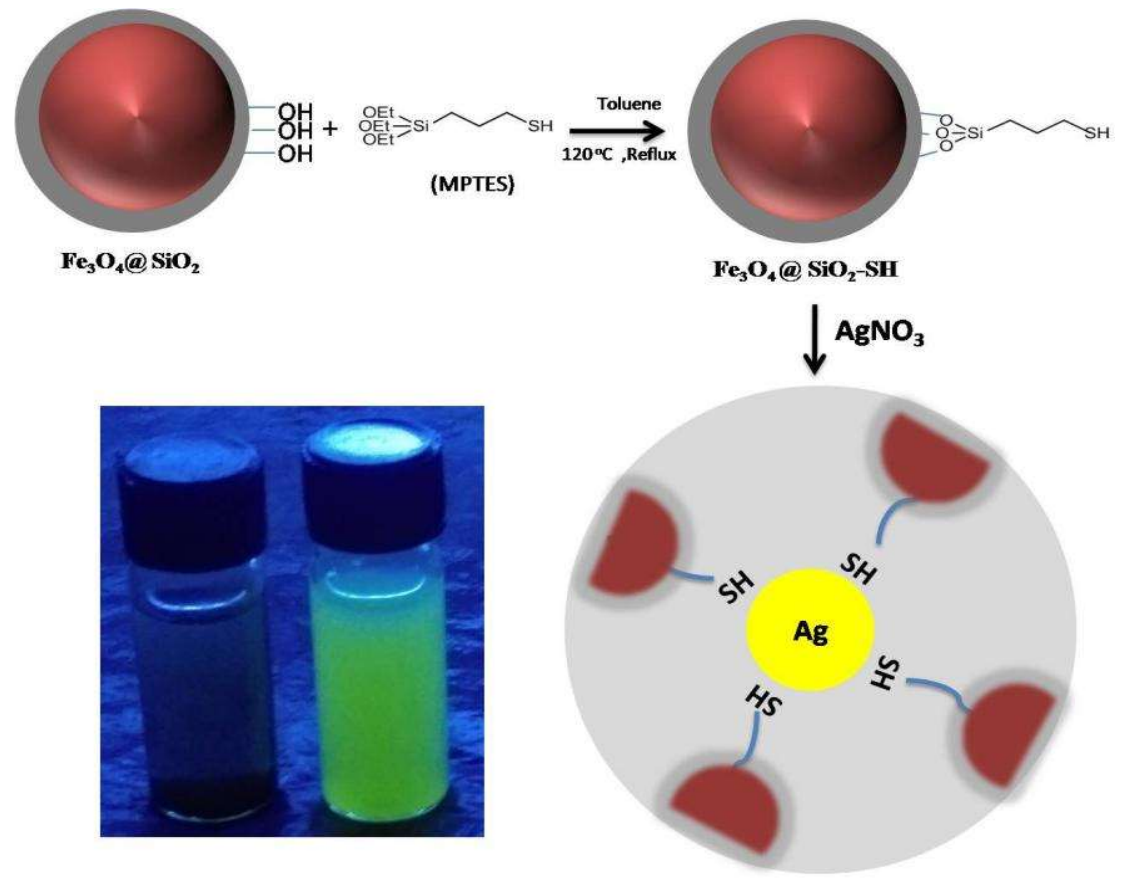

Scheme-1: Representation Diagrams for the Synthesis of $\mathrm{Fe}_{3} \mathrm{O}_{4} @ \mathrm{SiO}_{2}-\mathrm{SH}$ Sorbent and its Detection of Silver in Aqueous Solution (Photograph)

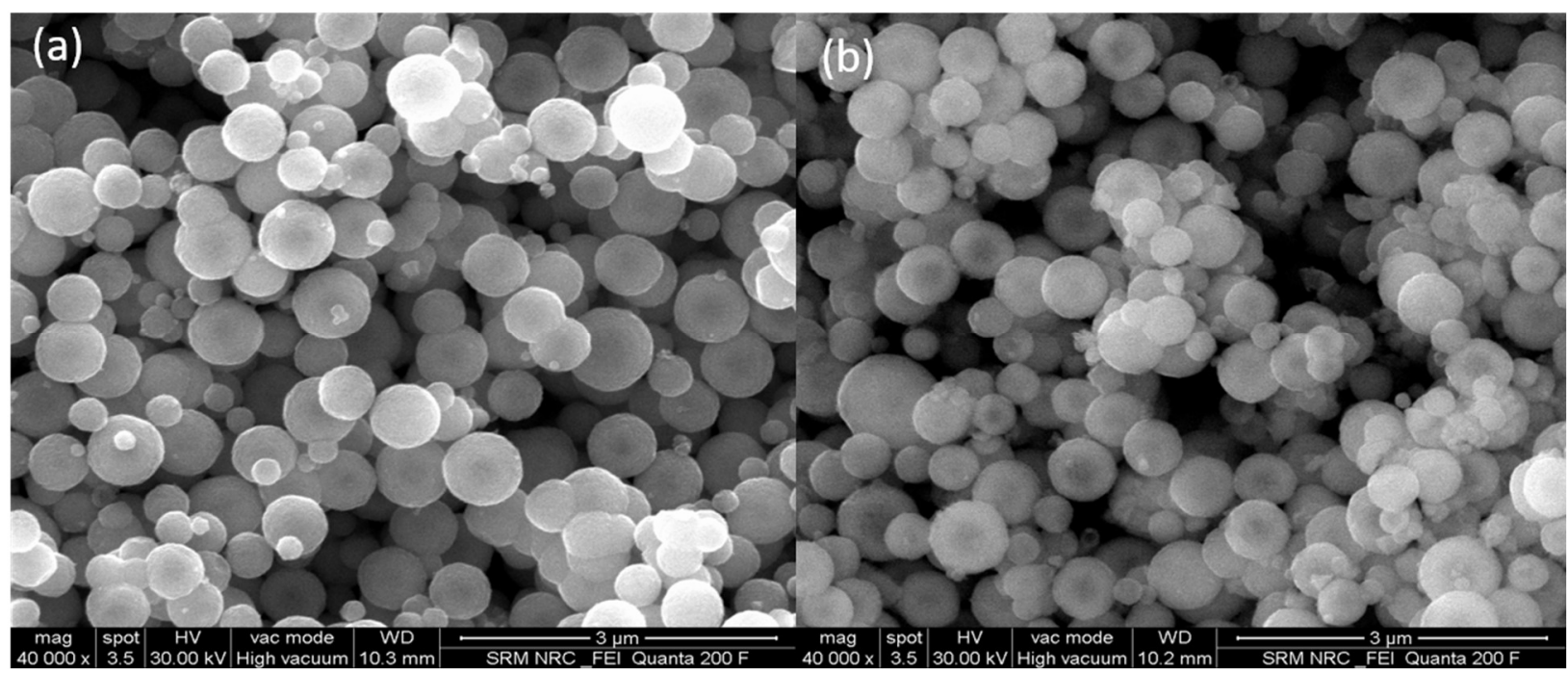

Fig.-1: The SEM Images of (a) $\mathrm{Fe}_{3} \mathrm{O}_{4}$ and (b) $\mathrm{Fe}_{3} \mathrm{O}_{4} @ \mathrm{SiO}_{2}$ 
RASĀYAN J. Chem.

Vol. 14 | No. 3 |1803-1808| July - September | 2021
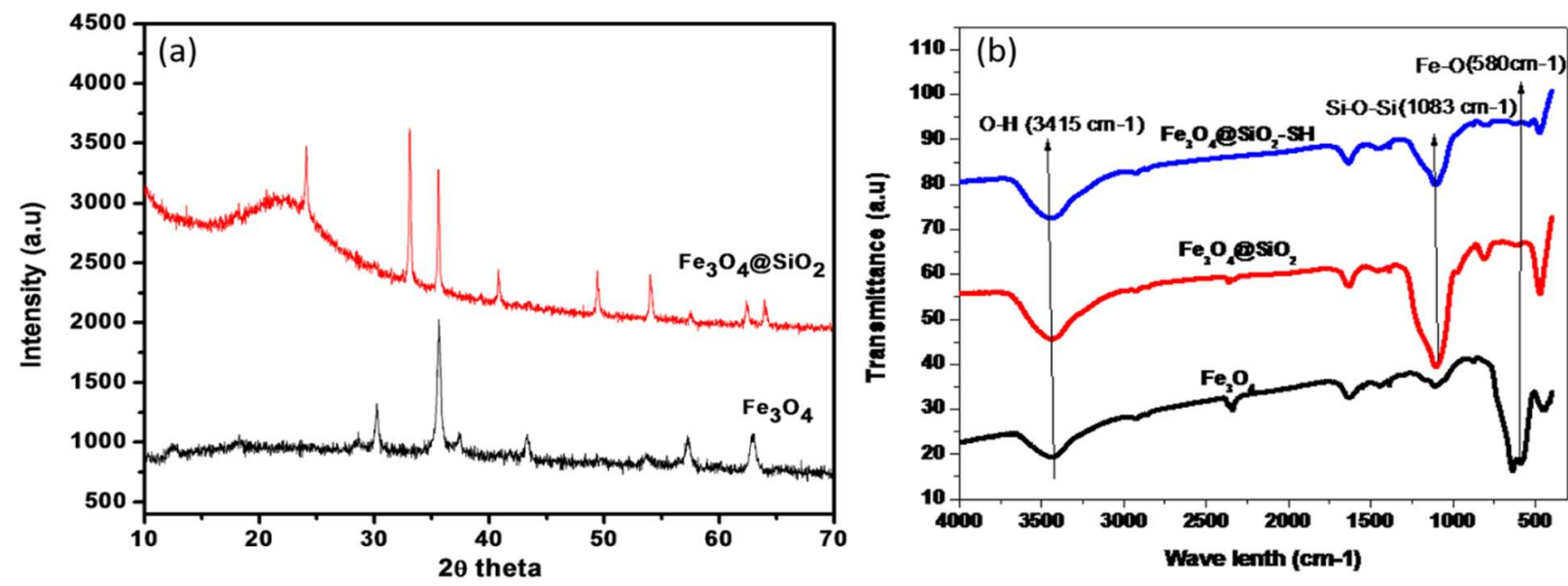

Fig.-2(a) XRD Patterns of the Samples of $\mathrm{Fe}_{3} \mathrm{O}_{4}$ and $\mathrm{Fe}_{3} \mathrm{O}_{4} @ \mathrm{SiO}_{2}$, (b) FT-IR Spectra of $\mathrm{Fe}_{3} \mathrm{O}_{4}, \mathrm{Fe}_{3} \mathrm{O}_{4} @ \mathrm{SiO}_{2}$ and $\mathrm{Fe}_{3} \mathrm{O}_{4} @ \mathrm{SiO}_{2}-\mathrm{SH}$

\section{Colorimetric Sensing of $\mathbf{A g}^{+}$Ions}

$\mathrm{UV}-\mathrm{V}$ is absorption spectra were taken for different materials such as $\mathrm{Fe}_{3} \mathrm{O}_{4} @ \mathrm{SiO}_{2}-\mathrm{SH}, \mathrm{Fe}_{3} \mathrm{O}_{4} @ \mathrm{SiO}_{2}$ and $\mathrm{Fe}_{3} \mathrm{O}_{4}$ shown in Fig.-3. Except for $\mathrm{Fe}_{3} \mathrm{O}_{4} @ \mathrm{SiO}_{2}-\mathrm{SH}$, other two materials like magnetic and silica-coated magnetic nanoparticles behave similarly not produce any absorption peaks in the range of 250-1100 nm indicate that the coating of silica layer not affect the SPR change of the magnetic nanoparticles. After the addition of silver ions in thiol functionalized silica coated core-shell nanoparticles, the yellow color of the solution was obtained because the formation of metal-thiol complexes and absorption peak appeared at 403 nm.

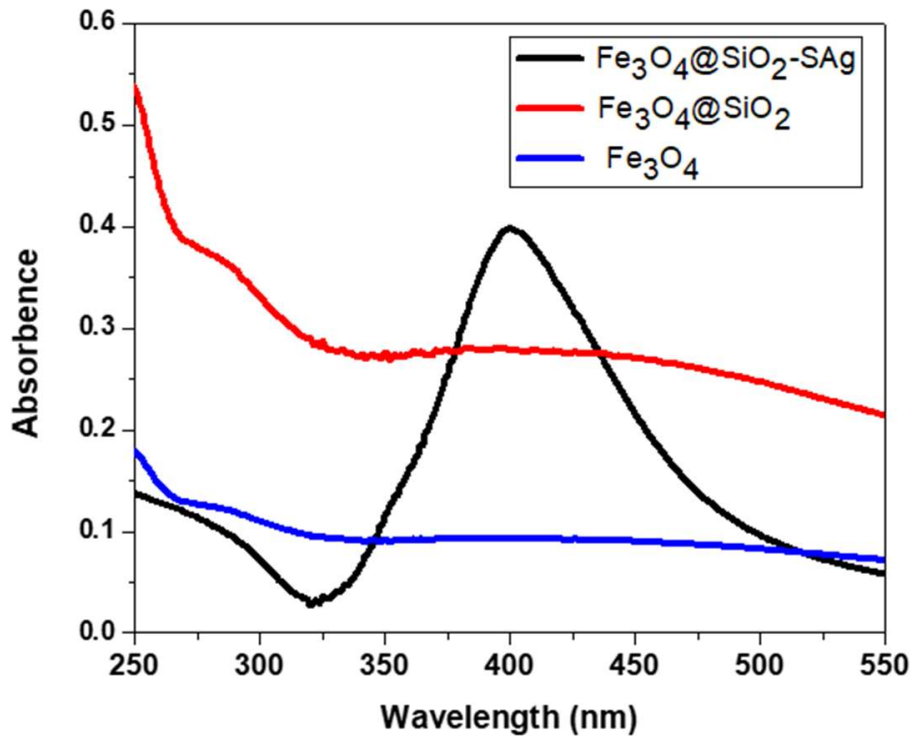

Fig.-3: UV-Vis Absorption Spectra of $\mathrm{Fe}_{3} \mathrm{O}_{4}, \mathrm{Fe}_{3} \mathrm{O}_{4} @ \mathrm{SiO}_{2}$ and $\mathrm{Fe}_{3} \mathrm{O}_{4} @ \mathrm{SiO}_{2}-\mathrm{SH}$

\section{Detection of $\mathbf{A g}^{+}$Ions}

The sensitivity study of the thiol functionalized silica-coated core-shell magnetic nanoparticles with silver ions in Fig.-4(a). Display the response of UV-Vis spectra of different $\mathrm{Ag}^{+}$ion concentrations (10-50 $\mathrm{mM}$ ). As the concentration of $\mathrm{Ag}^{+}$ions increases from 10 to $50 \mathrm{mM}$ in the solutions, corresponding to the absorption intensity also increases in the solutions. The detection limit of this colorimetric sensor is $10 \mathrm{mM}$, which is comparable to other colorimetric sensors. Figure- $4 \mathrm{~b}$ shows the graphical plot between the concentrations of silver ions and absorbance. A good linear relationship was observed with the correlation coefficient of 0.973 and the limit of the detection value of $10 \mathrm{nM}$ for $\mathrm{Ag}^{+}$ions based on the $3 \sigma$ method, 
RASĀYAN J. Chem.

Vol. 14 | No. 3 |1803-1808| July - September | 2021 which is analogous to other colorimetric sensors. The selectivity study was carried out with the proposed sensing system with $\mathrm{Ag}^{+}$and different metal ions. The UV absorption spectra were analyzed for $\mathrm{Ag}^{+}$and other counter metal ions. The $\mathrm{Pb}^{2+}$ and $\mathrm{Hg}^{2+}$ ions show weak absorption peaks and $\mathrm{Ag}^{+}$ions show a strong absorption peak at $403 \mathrm{~nm}$ in Fig. 4b. Other divalent metals such as $\mathrm{Ni}^{2+}, \mathrm{Co}^{2+}, \mathrm{Cu}^{2}, \mathrm{Zn}^{2+}, \mathrm{Mn}^{2+}$ and $\mathrm{Mg}^{2+}$ exhibit similar absorption intensity. Figure-4c clearly shows that only $\mathrm{Ag}^{+}$ions in the solution are able to produce an absorption peak in intensity at $403 \mathrm{~nm}$ with the yellow coloration. The other counter ions have negligible amounts of absorption peaks in UV absorption spectra evident that these ions have no interference with that of $\mathrm{Ag}^{+}$in the detection process. Therefore, $\mathrm{Fe}_{3} \mathrm{O}_{4} @ \mathrm{SiO}_{2}-\mathrm{SH}$ is an excellent colorimetric sensor for the determination of $\mathrm{Ag}^{+}$ions in an aqueous solution, which can be utilized for environmental applications.
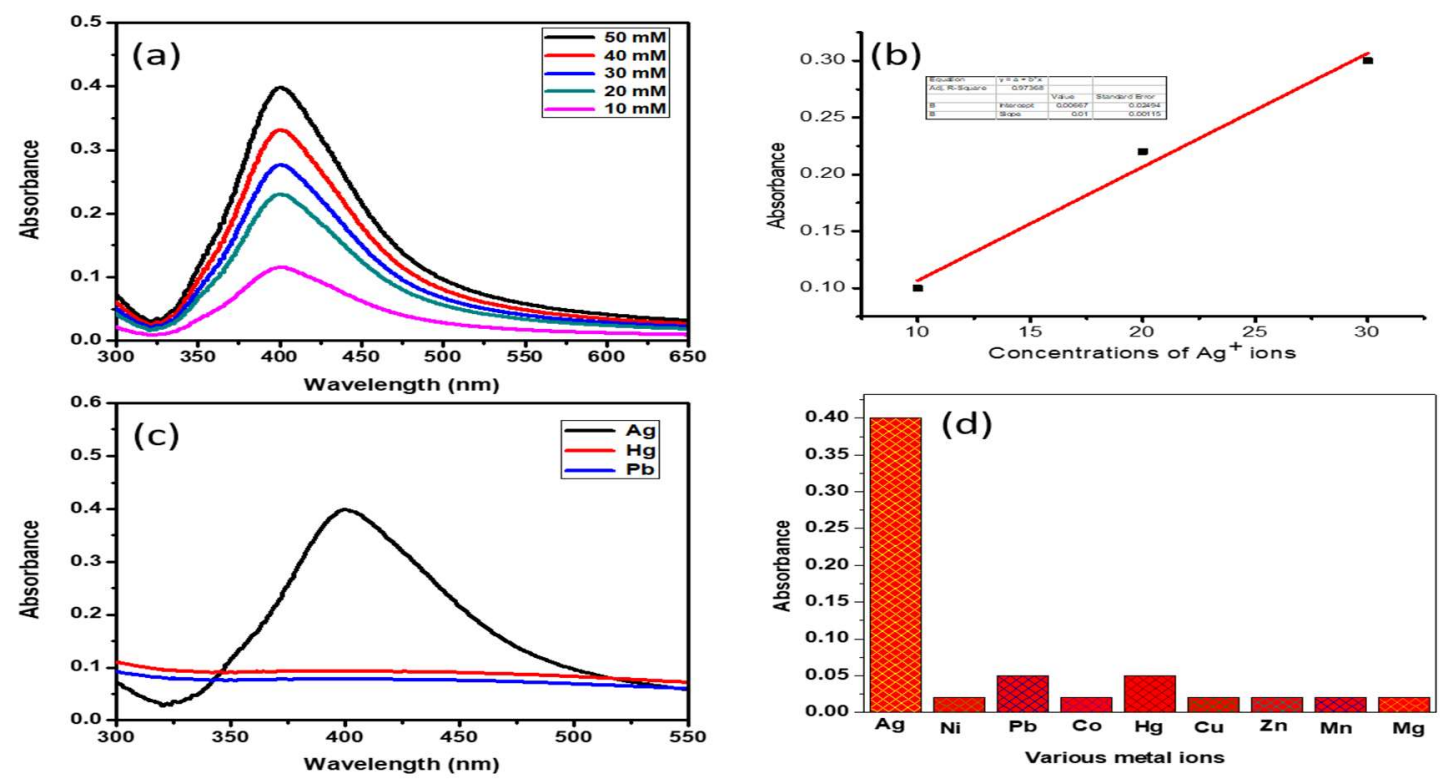

Fig.-4: (a)Graphical Plot for the Absorption Spectra Vs Concentrations of Silver Ions, (b) Linear Relationship

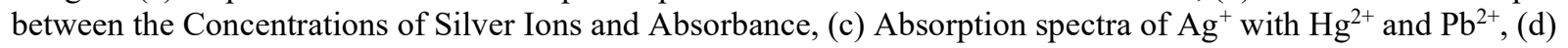
Selectivity Study of Different Metal Ions with Silver Ions

\section{Determination of $\mathrm{Ag}^{+}$in Real Water Samples}

The projected colorimetric sensing system was investigated with real water applications. The $\mathrm{Fe}_{3} \mathrm{O}_{4} @$ $\mathrm{SiO}_{2}-\mathrm{SH}$ nanoparticles used to analyze the tap water samples collected near the college campus since silver ions were absent. Samples were spiked with the silver nitrate stock solution of concentration $10 \mathrm{mM}, 20$ $\mathrm{mM}$ and $30 \mathrm{mM}$ and analyzed for the presence of silver in the samples. All the samples show promising data. The satisfactory results are tabulated in Table-1. The result confirms that the proposed sensor is more capable of the precise detection of $\mathrm{Ag}^{+}$in real water samples.

Table-1: The Amount of $\mathrm{Ag}^{+}$in Environmental Samples proposed by this Sensor.

\begin{tabular}{c|c|c|c}
\hline Sample & $\mathrm{Ag}^{+}$SPIKED $(\mathrm{mM})$ & Detected \pm SD & Recovery $(\%)$ \\
\hline \multirow{3}{*}{ TAP WATER } & 10 & $9.897 \pm 1.001$ & 97.94 \\
\cline { 2 - 4 } & 20 & $19.785 \pm 1.012$ & 97.85 \\
\cline { 2 - 4 } & 30 & $29.676 \pm 1.024$ & 98.38 \\
\hline
\end{tabular}

\section{CONCLUSION}

We have designed an inexpensive, simple, highly sensitive and choosy recognition of $\mathrm{Ag}^{+}$using a colorimetric sensor. The addition of thiol functionalized $\mathrm{Fe}_{3} \mathrm{O}_{4} @ \mathrm{SiO}_{2} \mathrm{NPs}$ with silver ions leads to the formation of metal-thiol complex with a change in color of solution due to the aggregation between NPs and silver ions. The interference of other metal ions with silver ions is negligible with the proposed sensing system. This colorimetric sensing method can achieve a detection limit of $\mathrm{Ag}^{+}$of $10 \mathrm{nM}$ in an aqueous 
RASĀYAN J. Chem.

Vol. 14 | No. 3 |1803-1808| July - September | 2021 solution. The potential application of the suggested sensor was studied in a real water sample. The results obtained show the projected sensor is more expeditious and economical for on-site detection of $\mathrm{Ag}^{+}$ions in environmental monitoring.

\section{REFERENCES}

1. L. Jarup, Hazards of heavy metal contamination, British Medical Bulletin, 68, 167 (2003), https://doi.org/10.1093/bmb/ldg032

2. A.T. Wan, R.A.J. Conyers, C.J. Coombs, J.P. Masterton, Determination of silver in blood, urine, and tissues of volunteers and burn patients, Clinical Chemistry, 37, 1683(1991), https://doi.org/10.1093/CLINCHEM/37.10.16831

3. J.L. Barriada, A.D. Tappin, E.H. Evans, E.P. Achterberg, Dissolved silver measurements in seawater, Trends in Analytical Chemistry,26,809(2007), https://doi.org/10.1016/j.trac.2007.06.004

4. X.-B. Zhang, Z.-X. Han, Z.-H. Fang, G.-L. Shen, R.-Q. Yu, 5,10,15-Tris (pentafluorophenyl) corrole as highly selective neutral carrier for a silver ion-sensitive electrode, Anaytica Chimica Acta, 562, 210 (2006), https://doi.org/10.1016/j.aca.2006.01.056

5. H.T. Ratte, Bioaccumulation and toxicity of silver compounds: a review, Environmental Toxicology Chemistry, 18, 89 (1999), https://doi.org/10.1002/etc.5620180112

6. S. Liau, D. Read, W. Pugh, J. Furr, A. Russell, Letter Application of Microbiology, 25,279(1997), https://doi.org/10.1046/j.1472-765X.1997.00219.x

7. K.B. Holt, A.J. Bard, Biochemistry, 44, 13214(2005), https://doi.org/10.1021/bi0508542

8. Ch. Mahendra, R.R. Sivakiran, K.A. Badrinarayana, Lakshmi Priya, Shivani Raj and M. Mamatha, Rasayan Journal of Chemistry, 13(2), 903(2020), https://doi.org/10.31788/RJC.2020.1325617

9. Y. Yang, W. Li, H. Qi, Q. Zhang, J. Chen, Y. Wang, B. Wang, S. Wang, C. Yu, Analytical Biochemistry, 430, 48(2012), https://doi.org/10.1021/bi0508542

10. Y. Cho, S.S. Lee, J.H. Jung, Analyst, 135, 1551(2010), https://doi.org/10.1039/C0AN00137F

11. H.K. Sung, S.Y. Oh, C. Park, Y. Kim, Langmuir, 29, 8978(2013), https://doi.org/10.1021/la401408f

12. D. Vilela, M.C. González, A. Escarpa, Analytical Chimica Acta,751, 24 (2012), https://doi.org/10.1016/j.aca.2012.08.043

13. J. Zeng, Y. Cao, J. Chen, X. Wang, J. Yu, B. Yu, Z. Yan, X. Chen, Nanoscale, 6,9939(2014), https://doi.org/10.1039/C4NR02560A

14. X. Tian, Z. Dong, R. Wang, J. Ma, Sensors and Actuators B, 183, 446(2013), https://doi.org/10.1016/j.snb.2013.03.124

15. E.T. Wahyuni,S. Suherman, D. Setyawati, R. Puspita, M.Mudasir, Rasayan journal. Chemistry, 13(1), 574(2020), https://doi.org/10.31788/RJC.2020.1315464

16. I. S. Budi, S. J. Santosa and E. S. Kunarti, Rasayan Journal of Chemistry, 13(1), 202(2020), https://doi.org/10.31788/RJC.2020.1315509

[RJC-6437/2021] 